\title{
PERAN MODAL SOSIAL SEBAGAI MEDIATOR LITERASI KEUANGAN DAN INKLUSI KEUANGAN PADA KAUM MUDA DI INDONESIA (STUDI KASUS PADA KOMUNITAS INVESTOR SAHAM PEMULA)
}

\author{
Rachmat Simbara Saputra', Andrieta Shintia Dewi² \\ Fakultas Ekonomi dan Bisnis, Universitas Telkom ${ }^{1,2}$
}

Email: rsimbara@students.telkomuniversity.ac.id', andrieta@telkomuniversity.ac.id²

\begin{abstract}
Currently the level of financial literacy and financial inclusion in Indonesian people, especially the younger generation, is still considered very low. Therefore, the role of social capital for improving financial literacy and financial inclusion in society need special attention. Social capital is expected to become a mediator for improving financial literacy and financial inclusion. This study aims to decide the role of social capital as a mediator of the relationship between financial literacy and financial inclusion. In addition, this study also examined the direct effect of financial literacy on financial inclusion. The population of this study were all members of the Investor Saham Pemula Community a number of 320 members. Making sample of this research using non-probability sampling technique with a sample size of 180 samples. This study adopts and uses Sobel and Kenny and Baron test to test the effect of mediation of social capital in the relationship between financial literacy and financial inclusion. The finding in this study is a proven social capital mediates the relationship between financial literacy and financial inclusion and there are no direct effect between financial literacy and financial inclusion.
\end{abstract}

Keywords: Financial Literacy, Financial Inclusion, Social Capital, Mediating Effect, Youth Indonesia 


\section{Rachmat Simbara Saputra}

\section{Andrieta Shintia Dewi}

\section{PENDAHULUAN}

Generasi muda saat ini telah menjadi fokus perhatian pemerintah dalam meningkatkan literasi dan inklusi keuangan mereka. OJK (2015) menyatakan akan menambah fokus dan prioritas sasaran edukasi keuangan kepada pelajar di Indonesia dari tingkat Universitas, SMA, SMP, hingga SD. OJK (2015) menjelaskan bahwa alasan regulator melakukan edukasi keuangan ke generasi muda adalah untuk membentuk financial habit sejak dini. Berdasarkan data dari SNLKI OJK (2014) tingkat literasi dan inklusi dalam berbagai industri keuangan di Indonesia adalah sebagai berikut:

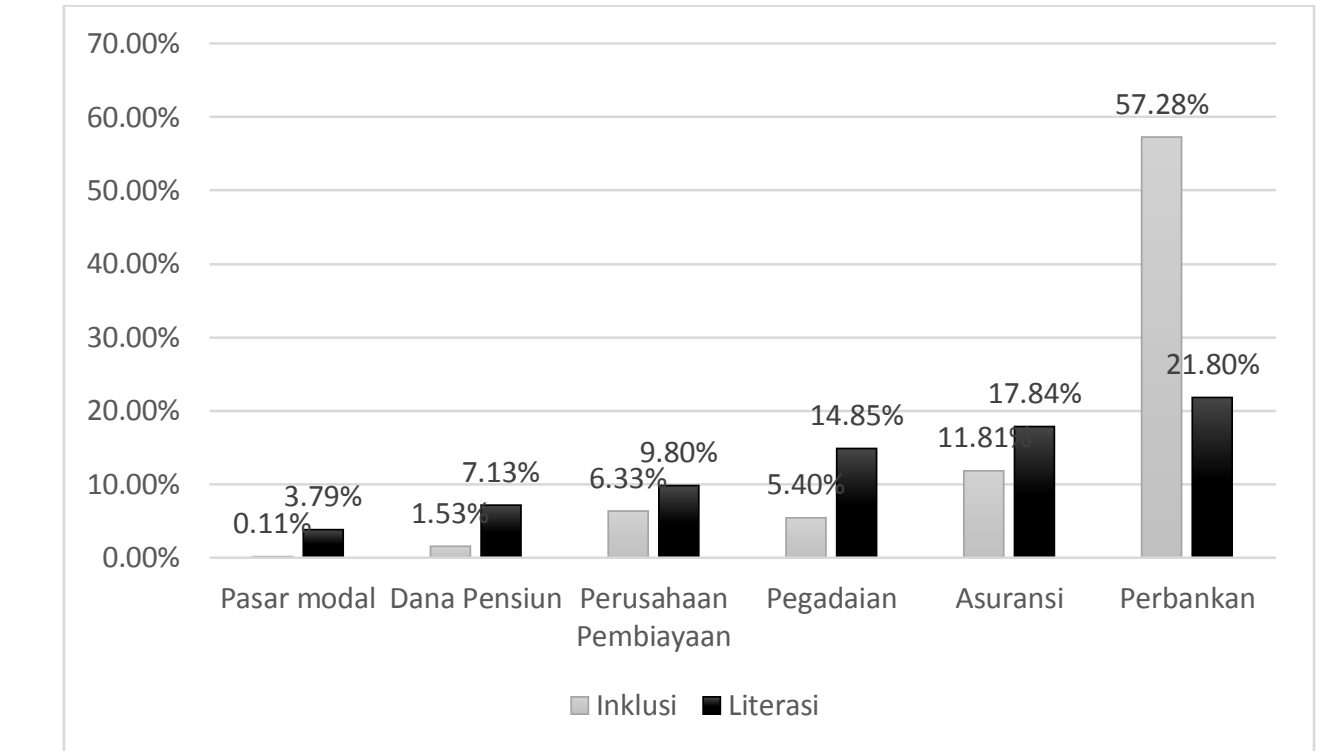

\section{Gambar 1 Grafik tingkat literasi dan inklusi dalam berbagai industri keuangan di Indonesia tahun 2013}

(Sumber: OJK, 2014)

Berdasarkan gambar 1 tingkat literasi keuangan masyarakat Indonesia paling tinggi pada lembaga keuangan perbankan yaitu sebesar $21,8 \%$ dan tingkat inklusi sebesar 57,28\%, sedangkan paling rendah pada pasar modal dimana tingkat literasi sebesar $3,79 \%$ dan tingkat inklusi sebesar $0,11 \%$, hal ini menunjukkan pasar modal harus menjadi fokus pemerintah dalam meningkatkan tingkat literasi dan inklusi di masyarakat. Menurut data dari Global Financial Inclusion Database (2015) hanya 36,1\% penduduk usia dewasa dan hanya $35,2 \%$ penduduk usia muda di Indonesia yang memiliki akun jasa keuangan. Untuk lebih jelasnya dapat dilihat di tabel 1.

Berdasarkan tabel 1 menunjukkan masih rendahnya tingkat inklusi masyarakat bahkan tingkat kepemilikan akun jasa keuangan generasi muda Indonesia masih tertinggal dibandingkan dengan Singapore, Malaysia, dan Thailand. Menurut OJK (2015) tingkat literasi keuangan pelajar baru sekitar $28 \%$ dengan tingkat inklusi keuangan sebesar $44 \%$. Padahal menurut Bank Indonesia (2016) keuangan inklusif mampu memberikan banyak manfaat yang dapat dinikmati oleh masyarakat, regulator, pemerintah, dan pihak swasta yaitu antara lain meningkatkan efisiensi ekonomi, mendukung stabilitas sistem keuangan, mengurangi shadow banking, mendukung pendalaman pasar keuangan, memberikan potensi pasar baru bagi perbankan, mendukung peningkatan Human Development Index, berkontribusi positif terhadap pertumbuhan ekonomi local dan nasional yang sustain dan berkelanjutan, mengurangi kesenjangan dan rigiditas low income trap, sehingga dapat 
meningkatkan kesejahteraan masyarakat yang pada akhirnya berujung pada penurunan tingkat kemiskinan. Manfaat tersebut didukung oleh penelitian Sharma (2016) yang menunjukkan bahwa terdapat hubungan positif antara pertumbuhan ekonomi dan berbagai dimensi inklusi keuangan, khususnya penetrasi perbankan, ketersediaan layanan perbankan dan penggunaan jasa perbankan dalam hal deposito.

Tabel 1 Persentase populasi penduduk yang mempunyai akun Bank di Indonesia dan beberapa Negara Asean lainnya tahun 2015

\begin{tabular}{|c|c|c|}
\hline Negara & Dewasa (umur 15+) & Dewasa Muda (15-24) \\
\hline Cambodia & $22,2 \%$ & $26,3 \%$ \\
\hline Indonesia & $36,1 \%$ & $35,2 \%$ \\
\hline Malaysia & $80,7 \%$ & $76,2 \%$ \\
\hline Myanmar & $22,8 \%$ & $13,5 \%$ \\
\hline Philippines & $31,3 \%$ & $19 \%$ \\
\hline Singapore & $96,4 \%$ & $92,9 \%$ \\
\hline Thailand & $78,1 \%$ & $70,6 \%$ \\
\hline Vietnam & $31,0 \%$ & $37,4 \%$ \\
\hline
\end{tabular}

Sumber : Global Financial Inclusion Database (2015)

Saat ini keuangan mikro semakin fokus pada mendorong budaya menabung, terutama pada kalangan pemuda. Sikap tidak gemar menabung ini dapat berakibat buruk terhadap tingkat kesejahteraan (Jamison et.al., 2014). Individu harus memiliki suatu pengetahuan dan keterampilan untuk mengelola sumber keuangan pribadinya secara efektif demi kesejahteraannya (Margaretha dan Pambudhi, 2015). Beberapa penelitian menunjukkan bahwa pengetahuan tentang literasi keuangan pada kaum muda masih rendah. Mendari dan Kewal (2013) dalam penelitiannya menunjukkan bahwa dari semua aspek literasi keuangan, mengindikasikan literasi keuangan yang rendah di kalangan kaum muda walaupun melalui pendidikan di sekolah sudah diberikan materi-materi perkuliahan yang berkaitan tentang aspek-aspek dalam literasi keuangan tersebut. Hal ini mengindikasikan bahwa literasi keuangan dan inklusi keuangan sangat penting untuk kalangan muda dan perlu menjadi perhatian serius bagi regulator untuk memperluas kerjasama dan menggandeng banyak pihak untuk meningkatkan literasi keuangan masyarakat salah satunya adalah modal sosial.

Modal sosial adalah tentang solidaritas, kepercayaan diri, dan memfasilitasi dalam menjalankan suatu bisnis, yang merupakan faktor yang berasal dari hubungan sosial yang melibatkan keluarga, teman, rekan kerja, dan lain-lain (Felicio et.al., 2014). Modal sosial diharapkan dapat menjadi salah satu alternatif pengembangan inklusi keuangan di Indonesia khususnya pada kaum muda. Salah satu modal sosial yang fokus pada pengembangan keuangan kaum muda adalah komunitas Investor Saham Pemula (ISP). Alasan dipilihnya komunitas ISP sebagai objek penelitian adalah karena komunitas tersebut fokus pada pengembangan keuangan, fokus pada kaum muda, dan tersebar di berbagai daerah di Indonesia. Persebaran Komunitas ISP ini ada di 26 daerah di Indonesia sehingga sangat layak untuk dijadikan studi kasus pada penelitian 
Mengingat adanya peran dari modal sosial dan pentingnya literasi keuangan dan inklusi keuangan pada kaum muda, maka peneliti bermaksud untuk meneliti peran modal sosial sebagai mediator literasi keuangan dan inklusi keuangan pada kaum muda di Indonesia. Beberapa penelitian berusaha menjelaskan peran modal sosial sebagai mediator pada aspek sosial ekonomi, tetapi penelitian tersebut tidak menjadikan kaum muda di Indonesia sebagai studi kasus.

\section{LANDASAN TEORI DAN PENGEMBANGAN HIPOTESIS}

Secara garis besar, peneliti akan melakukan :

1) Analisis hubungan literasi keuangan dan inklusi keuangan

2) Analisis peran modal sosial memediasi hubungan antara literasi keuangan dan inklusi keuangan

3) Analisis efek langsung literasi keuangan pada inklusi keuangan

Kerangka pemikiran secara keseluruhan ditunjukkan pada gambar 2 yang merupakan replikasi dari penelitian sebelumnya (Bongomin et.al., 2016) yang mengungkapkan bahwa terdapat peran modal sosial yang signifikan dalam memediasi hubungan antara literasi keuangan dan inklusi keuangan dan tidak terdapat efek langsung literasi keuangan pada inklusi keuangan

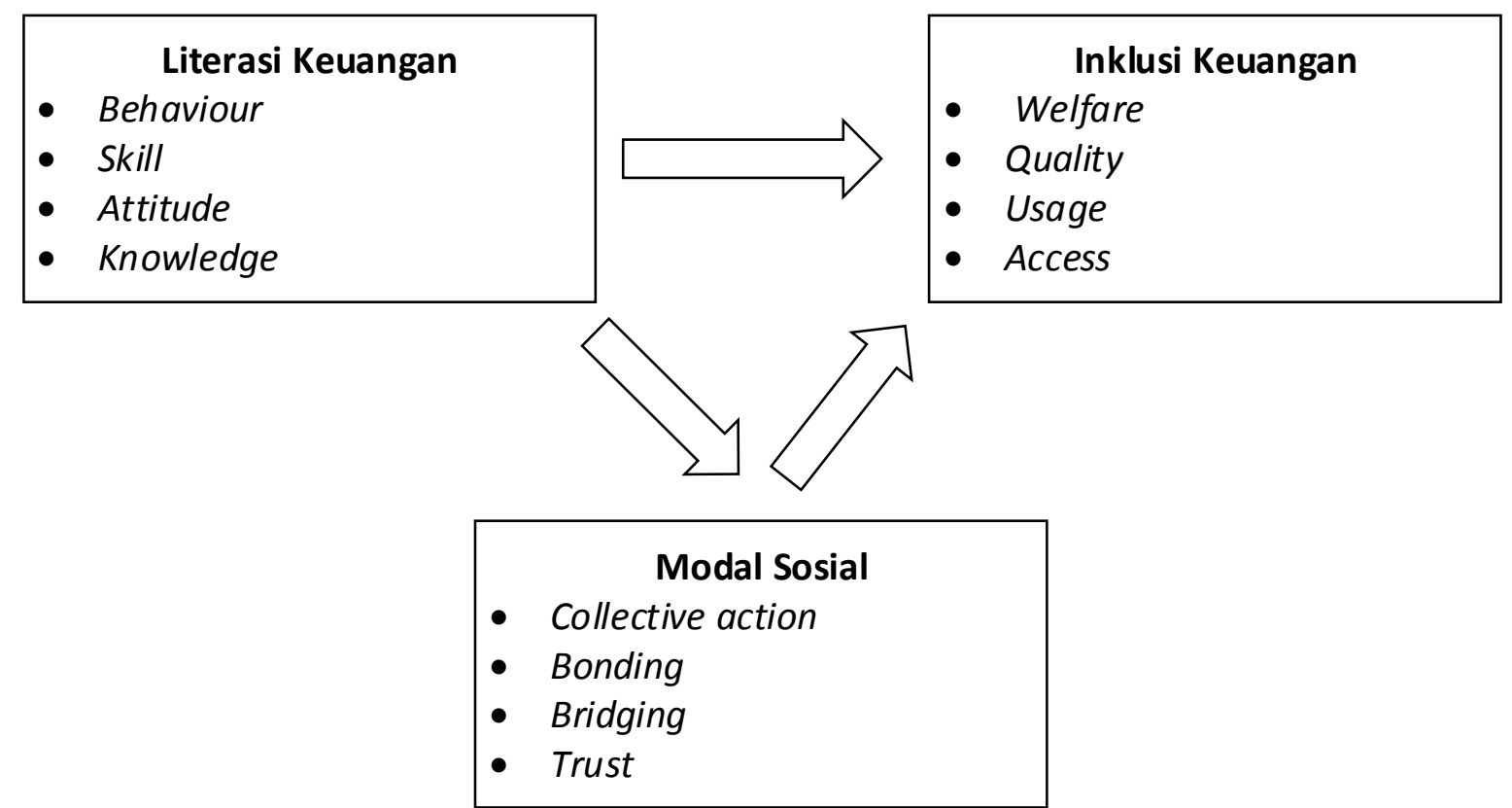

Gambar 2 Kerangka Pemikiran

\section{Literasi Keuangan}

Cohen dan Nelson (2011) menerangkan bahwa literasi keuangan dapat diasosiasikan dengan konsumen yang memiliki tanggung jawab untuk menginformasikan dirinya dari produk yang dia beli dan memahami kontrak yang dia tandatangani, hal tersebut termasuk pengetahuan (knowledge), keahlian (skill), dan sikap (attitude). Hung et.al. (2009) mencoba mendefinisikan literasi keuangan sebagai pengetahuan tentang konsep-konsep ekonomi dan keuangan dasar, serta kemampuan untuk menggunakan pengetahuan (knowledge) dan keterampilan (skill) keuangan lainnya dalam mengelola sumber daya keuangan secara efektif untuk kesejahteraan finansial. 


\section{Jurnal Manajemen Teori dan Terapan \\ Tahun 10. No. 3, Desember 2017}

OECD (2011) mendefinisikan literasi keuangan sebagai kombinasi kesadaran (awareness), kemampuan (skill), sikap (attitude), dan perilaku (behaviour) yang diperlukan untuk membuat keputusan keuangan yang sehar dan akhirnya mencapai kesejahteraan keuangan individu. Menurut OECD (2012) tujuan khusus dari literasi keuangan dapat berkisar dari kesadaran (awareness), keyakinan (confidence), pengetahuan (knowledge), dan pemahaman (understanding) konsumen dan investor pada masalah keuangan untuk membuat keputusan keuangan. Berdasarkan pemaparan dari Cohen dan Nelson (2011), Hung et.al (2009), OECD (2011), dan OECD (2012) maka dapat disimpulkan bahwa literasi kevangan adalah sikap dan perilaku seseorang dalam membuat penilaian informasi dan mengambil keputusan keuangan berdasarkan pengetahuan dan keterampilan mengelola keuangan untuk kesejahteraan finansial

\section{Inklusi Keuangan}

Menurut Consultative Group to Assist the Poor / G-20 Global Partnership for Financial Inclusion (CGAP/GPFI, 2010) adalah sebagai istilah yang mengacu pada keadaan dimana semua orang dewasa usia kerja memiliki akses yang efektif untuk layanan kevangan yang dapat diberikan oleh lembaga keuangan formal baik berupa kredit, tabungan (termasuk giro), pembayaran, dan asuransi. The Financial Action Task Forces (2011) mendefinisikan inklusi kevangan adalah tentang menyediakan akses ke lembaga keuangan yang memadai secara aman, nyaman, dan terjangkau layanan keuangannya untuk kelompok rentan yang kurang beruntung dan lainnya termasuk masyarakat berpenghasilan rendah, orang pedesaan dan tidak berdokumen, yang telah terlayani atau dikecualikan dari sektor keuangan formal. Atkinson dan Messy (2013) juga menerangkan bahwa inklusi keuangan adalah proses mempromosikan akses yang terjangkau, tepat waktu dan memadai untuk berbagai produk dan jasa keuangan yang diatur dan memperluas penggunannya oleh semua segmen masyarakat melalui penerapan pendekatan yang ada dan inovatif yang disesuaikan termasuk kesadaran keuangan dan pendidikan dengan tampilan untuk mempromosikan kesejahteraan keuangan serta inklusi ekonomi dan sosial. Memadai disini dapat diartikan sebagai memenuhi syarat atau dapat digunakan. Berdasarkan pemaparan dari CGAP/GPFI (2010), FATF (2011), dan Atkinson dan Messy (2013) dapat disimpulkan bahwa inklusi keuangan adalah istilah yang mengacu kepada keadaan dimana produk dan jasa keuangan dapat diakses, digunakan, dan memberikan manfaat serta kualitas layanan yang baik untuk meningkatkan kesejahteraan.

\section{Modal Sosial}

Modal sosial adalah pengorbanan individu (waktu, tenaga, dan konsumsi) yang dibuat dalam upaya untuk meningkatkan kerjasama dengan orang lain (Oxoby, 2009). Felicio et.al. (2014) juga menjelaskan bahwa modal sosial adalah tentang solidaritas, kepercayaan diri, dan memfasilitasi dalam menjalankan suatu bisnis, yang merupakan faktor yang berasal dari hubungan sosial yang melibatkan keluarga, teman, rekan kerja, dan lain-lain. Berdasarkan pemaparan dari Oxoby (2009) dan Felicio et.al. (2014) dapat disimpulkan bahwa modal sosial adalah sesorang atau kelompok yang mempercayai suatu pengetahuan, pemahaman, norma, aturan dan harapan terkait peran mengikat dengan hubungan interpersonal dan keanggotaan, serta penghubung jaringan sosial yang diimplementasikan dalam suatu aksi kolektif

\section{Penelitian Terdahulu dan Hipotesis}

Hubungan antara literasi keuangan dan inklusi keuangan dikemukakan oleh OECD (2013) bahwa kesadaran akan produk yang tersedia dalam suatu Negara merupakan prasyarat 


\section{Rachmat Simbara Saputra Andrieta Shintia Dewi}

penting bagi keuangan inklusi. Hal ini didukung oleh World Bank (2008) bahwa kapasitas individu dan pengusaha untuk mengambil keuntungan dari jasa keuangan yang tersedia juga tergantung pada pendidikan keuangan yang memadai. Cohen dan Nelson (2011) berpendapat bahwa pendidikan keuangan merupakan alat penting untuk mengatasi ketidakseimbangan dan membantu konsumen antara menerima dan menggunakan produk yang mana dapat meningkatkan aksesibilitas mereka. Potrich et.al. (2016) dalam penelitiannya menunjukkan bahwa pengetahuan keuangan dan sikap keuangan memiliki dampak positif pada perilaku keuangan. Zins dan Weill (2016) menemukan bahwa menjadi laki-laki, menjadi lebih kaya, menjadi lebih berpendidikan dan menjadi lebih dewasa mendukung inklusi keuangan dengan pengaruh pendidikan dan pendapatan yang lebih tinggi. Nkundabanyanga et.al. (2014) juga menerangkan terdapat hubungan yang positif dan signifikan antara perceived pinjaman bank, literasi keuangan, dan akses ke kredit formal.

H1 : Terdapat Hubungan antara Literasi Keuangan dan Inklusi Keuangan pada Kaum Muda

Kumar (2013) mengungkapkan pentingnya pengaturan sosial-ekonomi dan lingkungan suatu daerah dalam membentuk kebiasaan perbankan. Hal ini juga didukung oleh Bongomin et.al (2016) bahwa modal sosial memfasilitasi edukasi keuangan berupa pengetahuan dan keterampilan melalui interaksi dalam jaringan yang memainkan peran penting dalam meningkatkan inklusi keuangan. Bongomin et.al (2016) lebih lanjut mengemukakan bahwa modal sosial berperan penting dalam mediasi dan meningkatkan berbagi sumber daya termasuk pengetahuan dan keterampilan yang diperoleh masyarakat sebagai driver dari literasi keuangan. Kamukama dan Natamba (2013) dalam penelitiannya juga menemukan bahwa modal sosial secara parsial menengahi hubungan antara intermediasi sosial dan akses ke layanan keuangan.

H2 : Modal Sosial memediasi hubungan antara literasi keuangan dan inklusi keuangan pada Kaum Muda

Akan tetapi, menurut Bongomin et.al. (2016) dampak literasi keuangan pada inklusi kevangan meningkat jika terdapat modal sosial sebagai variabel mediasi. Ini berarti dampak literasi keuangan pada inklusi keuangan akan maksimal jika didorong oleh peran modal sosial sebagai mediator sehingga dapat dikatakan tidak terdapat efek langsung antara literasi keuangan pada inklusi keuangan.

H3: Tidak terdapat efek langsung literasi keuangan pada inklusi keuangan

\section{METODOLOGI}

\section{Sampel dan Populasi}

Populasi penelitian ini mengacu pada jumlah seluruh anggota komunitas ISP baik sebagai Ambassador maupun sebagai anggota yaitu berjumlah 320 anggota. Teknik pengambilan sampling yang digunakan adalah dengan non probability sampling sedangkan penentuan pengambilan jumlah responden (sampel) dilakukan melalui teknik quota sampling

Penentuan jumlah sampel minimal dihitung dengan menggunakan rumus Slovin yaitu:

$$
n=\frac{N}{1+N e^{2}}
$$

Dimana :

$\mathrm{n}=$ ukuran sampel

$\mathrm{N}=$ ukuran populasi 
e $\quad=5 \%$ (konstanta kelonggaran ketidaktelitian karena kesalahan pengambilan keputusan sampel yang masih dapat ditolerir)

Berdasarkan perhitungan dengan rumus Slovin dengan tingkat kelonggaran sebesar $5 \%$ didapat jumlah sampel minimal pada penelitian ini adalah berjumlah 180 responden.

\section{Data Penelitian}

Pada penelitian ini, data primer peneliti menggunakan kuesioner tertutup dengan pengukuran skala Likert's yang setiap instrumen disertai lima kemungkinan jawaban yang harus dipilih oleh responden yaitu poin (1) sangat tidak setuju, (2) tidak setuju, (3) netral, (4) setuju, dan (5) sangat tidak setuju. Kuesioner ini diadopsi dari penelitian sebelumnya dengan pertanyaan dalam variabel penelitian ini disesuaikan dengan keadaan objek penelitian. Sedangkan sumber data sekunder dari penelitian ini adalah berasal dari buku, jurnal, artikel website, berita online, penelitian sebelumnya, maupun sumber lain yang relevan.

\section{Variabel}

Variabel dalam penelitian diadopsi dari penelitian sebelumnya dan menghasilkan beberapa sub-variabel. Variabel Literasi Keuangan dikonsep menjadi empat sub variabel yaitu behaviour, skill, attitude, dan knowledge diadopsi dari Bongomin et al. (2016), Cohen dan Nelson (2011), Hung, et.al. (2009), dan OECD INFE. (2011).

Variabel Modal Sosial dikonsep menjadi empat sub variabel juga yaitu meliputi collective action, bonding, bridging, dan trust diadopsi dari Felicio et.al. (2014), Bongomin et al. (2016), dan Grootaert, et.al. (2004). Pertanyaan dalam variabel penelitian ini disesuaikan dengan keadaan objek penelitian.

Variabel Inklusi Keuangan dikonsep menjadi empat sub-variabel yaitu welfare, quality, usage, dan access diadopsi dari Bongomin et al. (2016). CGAP/GPFI (2010), Atkinson dan Messy (2013), dan FATF (2011). Pertanyaan dalam variabel penelitian ini disesuaikan dengan keadaan objek penelitian.

\section{Uji Validitas dan Uji Reliabilitas}

Merujuk pada Sarwono (2008 : 188) dimana pengambilan keputusan uji validitas jika $r$ hitung positif dan $\geq r$ tabel maka item pertanyaan tersebut valid. Nilai $r$ tabel diketahui 0,361 dengan taraf signifikansi $5 \%$. Untuk mencari nilai $r$ hitung peneliti menggunakan bantuan program SPSS for Windows v.20. setelah pengujian diketahui seluruh nilai $r$ hitung item pertanyaan valid kecuali item pertanyaan "pengeluaran saya sesuai dengan anggaran yang saya buat" maka dari itu item tersebut dihapus dalam daftar pertanyaan kuesioner.

Menurut Sarwono (2008:189) kriteria suatu instrumen reliabel jika nilai Alpha positif dan $>0,6$. Untuk mencari nilai Alpha peneliti menggunakan bantuan program SPSS for Windows v.20. Setelah pengujian diketahui seluruh variabel mempunyai nilai Alpha positif dan $>0,6$ yaitu literasi keuangan 0.765 , modal sosial 0.896 , dan inklusi keuangan 0.896 .

\section{Metode Analisis Data}

Metode analisis data yang digunakan adalah analisis deskriptif, analisis korelasi Pearson, dan analisis mediasi menggunakan Baron and Kenny and Sobel Test untuk mengukur pengaruh langsung dan pengaruh tidak langsung. Untuk analisis deskriptif menggunakan rumus sebagai berikut 


$$
\text { persentase }=\frac{\text { nilai } \text { kumulatif item }}{\text { nilai frekuensi }} \times 100 \%
$$

sedangkan untuk analisis korelasi Pearson adalah sebagai berikut

$$
r=\frac{\sum X Y}{\sqrt{\left(\sum X^{2}\right)\left(\sum Y^{2}\right)}}
$$

Untuk uji signifikansi perkiraan efek tidak langsung dari variabel independen terhadap variabel dependen menurut Sobel (dalam Baron dan Kenny, 1986) adalah :

$$
\sqrt{b^{2} s_{a}^{2}+a^{2} s_{b}^{2}+s_{a}^{2} s_{b}^{2}}
$$

dimana :

$a=$ variable independen

$\mathrm{Sa}=$ Standard error a

$\mathrm{b}=$ vaiabel dependen

$\mathrm{sb}=$ standar error $\mathrm{b}$

\section{PEMBAHASAN DAN KESIMPULAN}

\section{Karakteristik Sample}

Responden dalam penelitian ini adalah anggota komunitas Investor Saham Pemula di seluruh Indonesia. Pada penelitian ini, peneliti menyebarkan kuesioner kepada 180 responden. Kuesioner yang disebar terdiri dari tiga bagian, bagian pertama berupa screening question untuk menyaring responden yang sesuai dengan kriteria yang dapat mengisi kuesioner tersebut, kemudian bagian kedua berupa profil responden untuk mengetahui karakteristik responden tersebut, dan bagian ketiga berupa daftar pertanyaan tentang Literasi Keuangan, Modal Sosial, dan Inklusi Keuangan.

Berdasarkan 180 responden tersebut, didapat penggolongan responden berdasarkan asal daerah, jenis kelamin, usia, pendapatan, pendidikan terakhir, dan pekerjaan. Penggolongan tersebut dilakukan untuk memberikan gambaran karakteristik responden secara lebih detail

\begin{tabular}{|c|c|c|c|c|}
\hline No & Karakteristik & Unsur & Frekuensi & Persentase \\
\hline \multirow{4}{*}{1} & \multirow[t]{4}{*}{ Asal Daerah } & Pulau Jawa & 103 & $57 \%$ \\
\hline & & Pulau Sumatera & 55 & $31 \%$ \\
\hline & & Pulau Kalimantan & 11 & $6 \%$ \\
\hline & & $\begin{array}{l}\text { Pulau Sulawesi, Bali, } \\
\text { dan lainnya }\end{array}$ & 11 & $6 \%$ \\
\hline \multirow{2}{*}{2} & \multirow[t]{2}{*}{ Jenis Kelamin } & Laki-laki & 120 & $67 \%$ \\
\hline & & Perempuan & 60 & $33 \%$ \\
\hline \multirow{5}{*}{3} & \multirow[t]{5}{*}{ Usia } & 15-19 tahun & 45 & $25 \%$ \\
\hline & & 20-24 tahun & 116 & $64 \%$ \\
\hline & & 25-29 tahun & 18 & $10 \%$ \\
\hline & & 30-34 tahun & 1 & $1 \%$ \\
\hline & & $>34$ tahun & 0 & $0 \%$ \\
\hline \multirow{3}{*}{4} & \multirow[t]{3}{*}{ Pendapatan } & $<$ Rp.1.000.000 & 81 & $45 \%$ \\
\hline & & $\begin{array}{l}\text { Rp.1.000.000- } \\
\text { Rp.2.500.000 }\end{array}$ & 59 & $33 \%$ \\
\hline & & $\begin{array}{l}\text { Rp.2.500.000- } \\
\text { Rp.4.000.000 }\end{array}$ & 26 & $14 \%$ \\
\hline
\end{tabular}
sehingga memudahkan dalam menganalisis data.

Tabel 2 Karakteristik Sample 


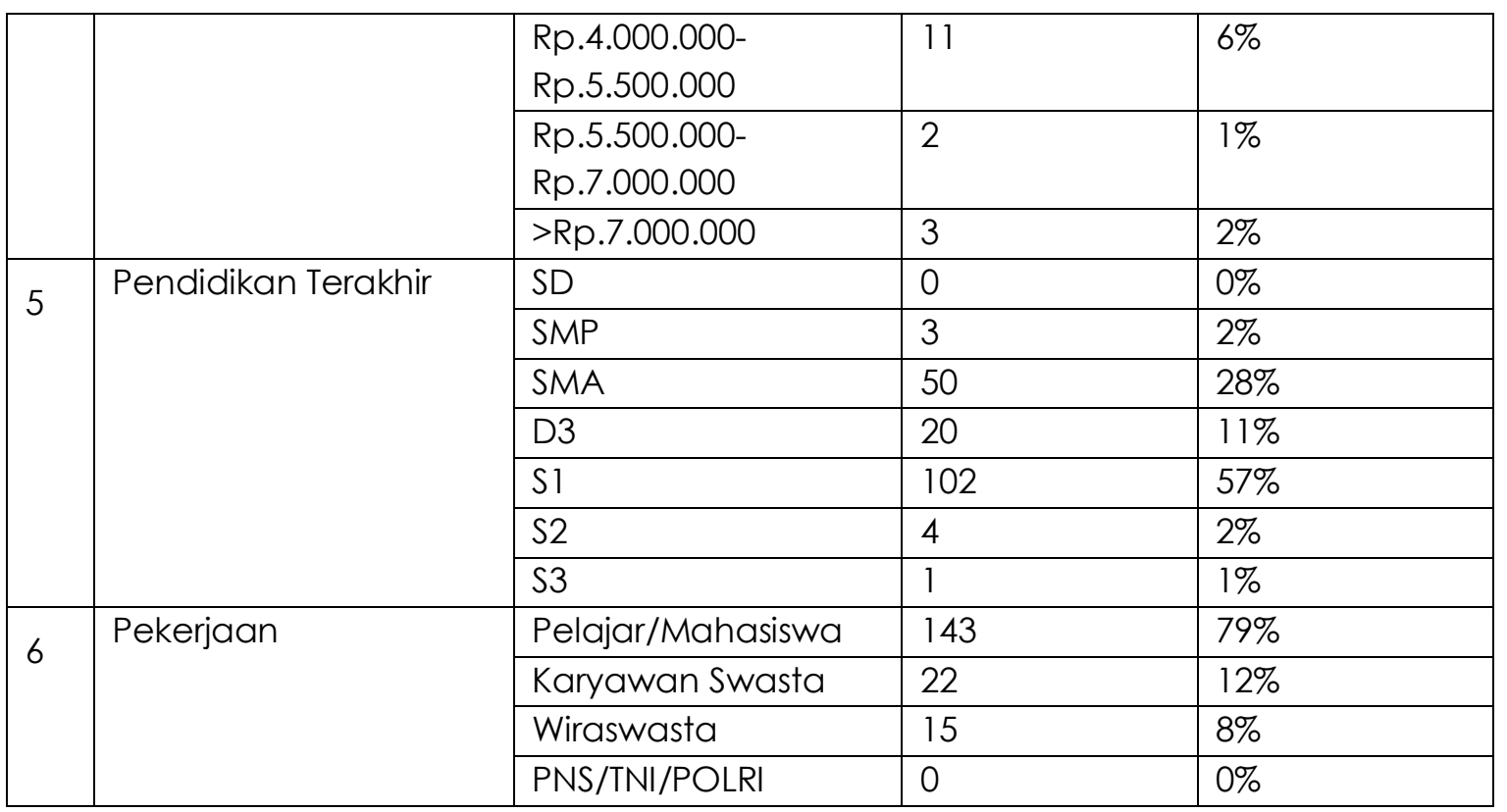

Berdasarkan asal daerah, dari Pulau Jawa masih mendominasi sebesar 57\%, hal ini juga karena pulau jawa memiliki jumlah penduduk tertinggi di Indonesia, berdasarkan jenis kelamin mayoritas adalah laki-laki sebesar $67 \%$ dan perempuan $33 \%$, hal ini menunjukkan minat investasi lebih banyak dilakukan laki-laki. Berdasarkan usia mayoritas antara umur 20-24 tahun, hal ini mengindikasikan bahwa komunitas ISP didominasi oleh kaum muda.

\section{Analisis Deskriptif}

Pada analisis deskriptif perlu dilakukan penghitungan jarak pengkategorian untuk nilai persentase tanggapan responden. Jumlah responden pada penelitian ini sebanyak 180 responden dengan persentase skor tanggapan pada tabel 8 berikut :

Tabel 3. Analisis Deskriptif

\begin{tabular}{|c|c|c|c|}
\hline Variabel & Sub-Variabel & $\begin{array}{l}\text { Persentase Rata-Rata } \\
\text { Skor }\end{array}$ & Kategori \\
\hline \multirow{4}{*}{$\begin{array}{l}\text { Literasi } \\
\text { Kevangan }\end{array}$} & Behavior & $78.3 \%$ & Baik \\
\hline & Skill & $80.2 \%$ & Baik \\
\hline & Attitude & $80.4 \%$ & Baik \\
\hline & Knowledge & $83.1 \%$ & Baik \\
\hline \multirow{4}{*}{ Modal Sosial } & Collection Action & $78.5 \%$ & Baik \\
\hline & Bonding & $80.3 \%$ & Baik \\
\hline & Bridging & $82.9 \%$ & Baik \\
\hline & Trust & $81.9 \%$ & Baik \\
\hline \multirow{4}{*}{ Inklusi Keuangan } & Welfare & $82.6 \%$ & Baik \\
\hline & Quality & $77.6 \%$ & Baik \\
\hline & Usage & $77.1 \%$ & Baik \\
\hline & Access & $83.1 \%$ & Baik \\
\hline
\end{tabular}

Berdasarkan tabel 8, temuan menunjukkan bahwa semua sub variabel termasuk dalam kategori baik. Kategori didasarkan dari pengelompokan rentang nilai dibagi 5 skala pengukuran, maka akan didapat nilai interval persentase sebesar $16 \%$. Dengan itu maka diperoleh rentang $20 \%$ - 36\% : sangat tidak baik, 36\% - 52\% : tidak baik, 52\% - 68\% : netral, $68 \%$ 
Rachmat Simbara Saputra

Andrieta Shintia Dewi

- 84\% : baik, $84 \%$ - 100\% : sangat baik. Hal ini dapat disimpulkan bahwa nilai-nilai dari literasi keuangan, modal sosial, dan inklusi keuangan pada komunitas ISP dalam kondisi baik.

\section{Analisis Korelasi Pearson}

Pada penelitian ini, peneliti menggunakan SPSS for windows V.20 sebagai alat bantu perhitungan. Hasil output dari SPSS tersebut adalah sebagai berikut :

Tabel 4 Hasil Analisis Korelasi Pearson

\section{Correlations}

\begin{tabular}{|r|r|r|r|}
\hline & Literasi_Keuangan & Modal_Sosial & Inklusi_Keuangan \\
\hline $\begin{array}{l}\text { Pearson } \\
\text { Correlation } \\
\text { Literasi_Keuangan }\end{array}$ Sig. (2- \\
tailed) \\
N
\end{tabular}

**. Correlation is significant at the 0.01 level (2-tailed).

sumber : data diolah

Berdasarkan tabel 9 diatas dapat dilihat bahwa nilai $r$ korelasi antara variabel literasi keuangan dan modal sosial sebesar 0,645, artinya kedua variabel memiliki korelasi yang positif dengan tingkat hubungan termasuk dalam kategori kuat. Kemudian nilai $r$ korelasi antara variabel literasi keuangan dan inklusi kevangan adalah sebesar 0,661, artinya artinya kedua variabel memiliki korelasi yang positif dengan tingkat hubungannya termasuk dalam kategori kuat. Hal ini berarti semakin tinggi literasi keuangan yang dimiliki seseorang akan meningkatkan partisipasinya dalam modal sosial dan meningkatkan tingkat inklusi kevangannya. Selanjutnya nilai $r$ korelasi antara variabel modal sosial dan inklusi keuangan adalah sebesar 0,754 , artinya artinya kedua variabel memiliki korelasi yang positif dengan tingkat hubungannya termasuk dalam kategori kuat. Jadi, jika seseorang aktif dalam modal sosial maka hal tersebut dapat meningkatkan inklusi keuangan orang tersebut.

Berdasarkan penjelasan diatas dapat membuktikan $\mathrm{Hl}$ bahwa terdapat hubungan yang signifikan antara literasi keuangan dan inklusi keuangan. Dengan adanya korelasi tersebut maka penelitian ini memenuhi syarat untuk mengukur mediator dari variabel tersebut 
mengacu pada Baron dan Kenny (1986) bahwa karena variabel independen diasumsikan menyebabkan mediator, kedua variabel tersebut harus berkorelasi.

\section{Analisis Mediasi}

Pada analisis ini akan diukur efek mediasi modal sosial pada hubungan antara literasi keuangan dan inklusi keuangan. Perhitungan nilai signifikansi efek mediasi menggunakan alat bantu SPSS for windows v.20 dengan prosedur proses dari Andrew F. Hayes. Hasil dari perhitungan efek mediasi tersebut dijelaskan dalam tabel 10 berikut:

Tabel 5 Efek Mediasi Modal Sosial pada Hubungan Antara Literasi Keuangan dan Inklusi Kevangan

\begin{tabular}{|l|c|c|c|r|r|r|}
\hline & \multicolumn{3}{|c|}{ Modal Sosial } & \multicolumn{3}{c|}{ Inklusi Keuangan } \\
\cline { 2 - 7 } & $t$ & SE & coeff & $t$ & SE & coeff \\
\hline Literasi Keuangan & 11.2552 & 0.766 & 0.8616 & 4.9343 & 0.698 & 0.3444 \\
\hline Modal Sosial & & & & 9.2785 & 0.522 & 0.4846 \\
\hline
\end{tabular}

Sumber : data diolah

Berdasarkan tabel 10 diatas dapat diketahui dengan tingkat kepercayaan $95 \%$ koefisien nilai literasi keuangan dan modal sosial sebesar 0.8616, ini berarti nilai koefisien lebih besar daripada nilai signifikansi $(0.8616>0.05)$, dengan itu dapat disimpulkan bahwa ada hubungan yang signifikan antara literasi keuangan dan modal sosial. Begitu juga dengan nilai koefisien modal sosial dan inklusi keuangan sebesar 0.4846, ini berarti nilai koefisien lebih besar daripada nilai signifikansi $(0.4846>0.05)$, dengan itu dapat disimpulkan bahwa terdapat hubungan yang signifikan antara modal sosial dan inklusi keuangan. Berdasarkan penjelesan tersebut dapat diketahui bahwa modal sosial menengahi hubungan antara literasi keuangan dan inklusi keuangan sekaligus membuktikan bahwa H2 diterima.

Tahap analisis selanjutnya adalah mencari tahu apakah terdapat efek langsung literasi keuangan pada inklusi keuangan atau tidak. Hasil dari perhitungan efek langsung literasi keuangan pada inklusi keuangan dapat dilihat pada tabel 11 berikut :

Tabel 6 Total Efek, Efek Langsung, dan Efek Tidak Langsung Literasi Keuangan pada Inklusi Keuangan.

\begin{tabular}{|c|c|c|c|c|c|c|}
\hline \multicolumn{7}{|c|}{ Total effect of $X$ on $Y$} \\
\hline & Effect & SE & $t$ & $\mathrm{p}$ & $\mathrm{LLCl}$ & ULCI \\
\hline & ,7619 & 0649 & 11,7483 &, 0000 & 6339 & ,8899 \\
\hline \multicolumn{7}{|c|}{ Direct effect of $X$ on $Y$} \\
\hline & Effect & SE & $t$ & $\mathrm{p}$ & $\mathrm{LLCl}$ & $\mathrm{ULCl}$ \\
\hline & 3444 &, 0698 & 4,9343 &, 0000 & 2066 &, 4821 \\
\hline \multicolumn{7}{|c|}{ Indirect effect of $X$ on $Y$} \\
\hline & Effect & Boot SE & BootLLCl & Bootl & $\mathrm{LCl}$ & \\
\hline Modal_So & 4175 & 0711 & 2903 & & 09 & \\
\hline
\end{tabular}

Sumber : data diolah 
Berdasarkan tabel 11 diatas dapat dilihat bahwa total efek literasi kevangan pada inklusi keuangan sebesar 0.7619, hal ini terdiri dari efek langsung sebesar 0.3444 dan efek tidak langsung yang melalui modal sosial sebesar 0.4175. Hal ini menunjukkan bahwa efek tidak langsung literasi keuangan pada inklusi keuangan yang melalui modal sosial lebih besar daripada efek langsung literasi keuangan pada inklusi keuangan (0.4175>0.3444). Hasil ini membuktikan $\mathrm{H} 3$ diterima bahwa modal sosial sepenuhnya memediasi hubungan antara literasi keuangan dan inklusi keuangan. Jadi, dapat disimpulkan bahwa literasi keuangan akan lebih berpengaruh terhadap inklusi keuangan jika melalui modal sosial, artinya inklusi keuangan seseorang yang mengikuti modal sosial berpeluang besar lebih tinggi dibandingkan seseorang yang tidak mengikuti modal sosial.

Tabel 7 Hasil Sobel Test

\begin{tabular}{|c|c|c|c|}
\hline \multicolumn{4}{|c|}{ Normal theory tests for indirect effect } \\
\hline Effect & se & Z & $\mathrm{p}$ \\
\hline, 4175 &, 0585 & 7,1426 &, 0000 \\
\hline
\end{tabular}

Sumber : data diolah

Lebih dari itu, jika merujuk pada nilai Sobel Z-test seperti ditunjukkan pada tabel 12 sebesar 7.1426 lebih besar dari nilai signifikansi sebesar 0.05. Hasil ini menunjukkan bahwa ada peran mediasi modal sosial dalam hubungan literasi keuangan dan inklusi keuangan. Seperti yang telah dijelaskan sebelumnya, bahwa hal ini mempertegas peran modal sosial dalam kaitannya sebagai variabel mediasi, menunjukkan peningkatan yang signifikan dampak literasi keuangan pada inklusi keuangan dibandingkan dengan ketika literasi keuangan diselidiki sendiri sebagai prediktor utama inklusi keuangan. Untuk lebih jelasnya dapat dilihat pada gambar 3 berikut :

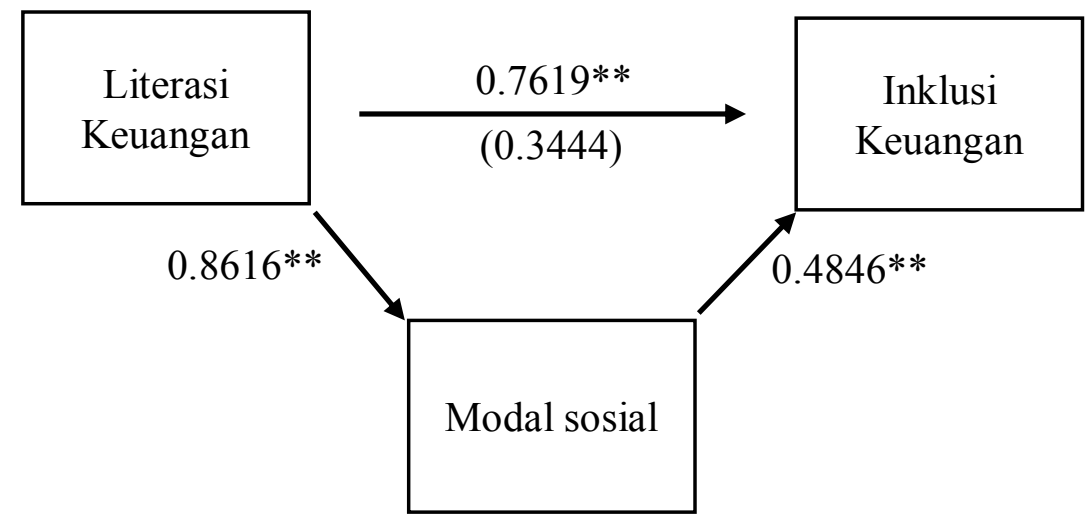

Gambar 3 Hasil Sobel Z-Test

(sumber : data diolah)

\section{KESIMPULAN}

Penelitian ini berhasil menemukan bukti bahwa terdapat hubungan yang signifikan antara literasi keuangan dan inklusi keuangan. Juga terdapat peran modal sosial yang signifikan sebagai mediator antara literasi keuangan dan inklusi keuangan. Selain itu juga penelitian mendapat temuan bahwa dampak literasi keuangan pada inklusi keuangan akan meningkat jika terdapat peran dari modal sosial, hal ini berarti efek langsung literasi keuangan pada inklusi keuangan dapat dikatakan rendah. 


\section{Jurnal Manajemen Teori dan Terapan \\ Tahun 10. No. 3, Desember 2017}

\section{IMPLIKASI DAN KETERBATASAN}

\section{Saran untuk regulator}

Regulator dapat memanfaatkan modal sosial seperti komunitas untuk meningkatkan literasi keuangan dan inklusi keuangan di masyarakat. Regulator diharapkan membuat program yang bekerjasama dengan komunitas yang terbukti dapat memberikan dampak yang signifikan dan dilakukan secara berkelanjutan sehingga manfaat yang diterima masyarakat akan lebih terasa.

\section{Saran untuk komunitas}

Komunitas dapat menjadi agen penggerak untuk peningkatan literasi keuangan dan inklusi keuangan di masyarakat. Khusus untuk komunitas ISP, perlu dicermati bahwa pada variabel modal sosial, sub-variabel collection action mendapat skor paling rendah jika dibandingkan dengan sub-variabel yang lain. Oleh karena itu, komunitas ISP perlu melakukan inovasi untuk meningkatkan aksi kolektif anggotanya.

\section{Saran untuk penelitian selanjutnya}

Objek penelitian pada penelitian ini adalah kaum muda di Indonesia. Untuk penelitian selanjutnya akan lebih baik jika objek penelitian lebih diarahkan kepada kelompokkelompok yang rentan terhambat dalam pemenuhan kebutuhan keuangannya seperti kaum difabel, para imigran, maupun masyarakat berpenghasilan rendah. Penelitian ini juga memiliki keterbatasan yaitu waktu pelaksanaannya bersifat cross section sehingga hanya mewakili kondisi pada saat periode tersebut. Pada penelitian selanjutnya dapat mempertimbangkan untuk penelitian secara longitudinal.

\section{DAFTAR PUSTAKA}

Atkinson, A. dan Messy, F. (2013), Promoting Financial Inclusion through Financial Education: OECD/INFE Evidence,Policies and Practice", OECD Working Papers on Finance, Insurance and Private Pensions, No. 34, OECD Publishing. http://dx.doi.org/10.1787/5k3xz6m88smp-en

Bl. (2016). Kevangan Inklusif di Indonesia. [online]. http://www.bi.go.id/id/perbankan/keuanganinklusif/Indonesia/Contents/Default.aspx . [30 Juli 2016]

Baron, Reuben dan Kenny, David A. (1986). The Moderator-Mediator Variable Distiction in Social Psychological Research : Conseptual, Strategic, and Statistical Considerations. Journal of Personality and Social Psychology. 6(51). 1173-1182.

Bongomin et al. (2016). Social Capital : Mediator of Financial Literacy and Financial Inclusion in Rural Uganda. Review of International Business and Strategy. 26(2). 291-312.

CGAP/GPFI. (2010). Global Standard-Setting Bodies and Financial Inclusion for the Poor: Toward Proportionate Standards and Guidance. Global Partnership for Financial Inclusion.

Cohen, Monique dan Nelson, Candace. (2011). Financial Literacy: A Step for Clients Towards Financial Inclusion. Valladolid: Global Microcredit Summit 2011.

FATF. (2011). FATF Guidance : Anti-Money Laundering and Terrorist Financing Measures and Financial Measures and Financial Inclusion. Financial Action Task Forces.

Felicio, J Augusto et.al. (2014). Human Capital, Social Capital, and Organizational Performance. Management Decision. 2(52). 350-364.

Global Financial Inclusion Database. (2015). The Little Data Book on Financial Inclusion. Wolrd 
Bank Group.

Grootaert, et.al. (2004). Measuring Social Capital : An Integrated Questionnaire. World Bank Working Paper. Wolrd Bank Group.

Hung, et.al. (2009). Defining and Measuring Financial Literacy. RAND Labor and Population Working Paper Series. WR-708.

Jamison, Julian C et. al. (2014). Financial Education and Acccess to Savings Accounts: Complements or Susbtitutes? Evidence from Ugandan Youth Club. NBER Working Paper Series 20135. National Bureau of Economic Research.

Kamukama, Nixon dan Natamba, Bazinzi. (2013). Social Capital : Mediator of Social Intermediation and Financial Services Access. International Journal of Commerce and Management. 3(23). 204-215.

Kumar, Nitin. (2013). Financial Inclusion and Its Determinants : Evidence from India. Journal of Financial Economic Policy. 1(5). 4-19

Margaretha, Farah dan Pambudhi, Reza. (2015). Tingkat Literasi Keuangan pada Mahasiswa s-1 Fakultas Ekonomi. Jurnal Manajemen Keuangan.17(1). 76-85.

Mendari, Anastasia Sri dan Kewal, Suramaya. (2013). Tingkat Literasi Keuangan di Kalamangan Mahasiswa STIE Musi. Jurnal Economia. 9(2). 130-140.

Nkundabanyanga et.al. (2014). Lending Terms, Financial Literacy, and Formal Credit Accessibility. International Journal of Social Economics. 5(41). 342-361.

OECD INFE. (2011). Measuring Financial Literacy : Core Questionnaire in Measuring Financial Literacy: Questionnaire and Guidance Notes for Conducting an Internationally Comparable Survey of Financial Literacy. Paris : OECD.

OECD INFE. (2012). High-Level Principles on National Strategies for Financial Education. Paris : OECD.

OECD INFE. (2013). The Role of Financial Education in Financial Inclusion : OECD / INFE Evidence, Policies and Illustrative Case Studies. Moscow : G20 Communiqué Meeting of Finance Ministers and Central Bank Governors.

OJK. (2014). Implementasi Strategi Nasional Literasi Keuangan Indonesia. Otoritas Jasa Kevangan.

OJK. (Maret 2015). OJK Ciptakan Financial Habit Agar Pelajar Melek Keuangan. Edukasi Konsumen. [online]. $\quad$ 8.9. Tersedia http://sikapivangmu.ojk.go.id/FrontEnd/CMS/Download/15 [15 September 2016].

Oxoby, Robert. (2009). Understanding Social Inclusion, Social Cohesion, and Social Capital. International Journal of Social Economics. 12(36). 1133-1152.

Potrich, Ani Caroline et.al. (2016). Development of A Financial Literacy Modal for University Students. Management Research Review. 3(39). 356-379.

Sarwono, Jonathan. (2008). Riset Bisnis untuk Pengambilan Keputusan. Yogyakarta : Andi.

Sharma, Dipasha. (2016). Nexus Between Financial Inclusion and Economic Growth. Journal of Financial Economic Policy. 1 (8). 13-36.

World Bank. (2008). Finance for All? : Policies and Piffalls in Expanding Access.Washington DC : World Bank Group.

Zins, Alexandra dan Weill, Laurent. (2016). The Determinants of Financial Inclusion in Africa. 
Jurnal Manajemen Teori dan Terapan

Tahun 10. No. 3, Desember 2017

Review of Development Finance. 1(6). 46-57. 